\title{
Preparation and Electrocatalytic Characteristics Research of Pd/C Catalyst for Direct Ethanol Fuel Cell
}

\author{
Qiao Xia Li, Ming Shuang Liu, Qun Jie Xu, and Hong Min Mao \\ Shanghai Key Laboratory of Colleges and Universities for Corrosion Control in Electric Power System and Applied Electrochemistry, \\ Shanghai University of Electric Power, Shanghai 200090, China
}

Correspondence should be addressed to Qun Jie Xu; xuqunjie@shiep.edu.cn

Received 31 October 2012; Revised 7 January 2013; Accepted 21 January 2013

Academic Editor: Valeria La Parola

Copyright (C) 2013 Qiao Xia Li et al. This is an open access article distributed under the Creative Commons Attribution License, which permits unrestricted use, distribution, and reproduction in any medium, provided the original work is properly cited.

Two kinds of carbon-support 20\% Pd/C catalysts for use in direct ethanol fuel cell (DEFC) have been prepared by an impregnation reduction method using $\mathrm{NaBH}_{4}$ and $\mathrm{NaH}_{2} \mathrm{PO}_{2}$ as reductants, respectively, in this study. The catalysts were characterized by XRD and TEM. The results show that the catalysts had been completely reduced, and the catalysts are spherical and homogeneously dispersed on carbon. The electrocatalytic activity of the catalysts was investigated by electrochemical measurements. The results indicate that the catalysts had an average particle size of $3.3 \mathrm{~nm}$ and showed the better catalytic performance, when $\mathrm{NaBH}_{4}$ was used as the reducing agent. The electrochemical active surface area of $\mathrm{Pd} / \mathrm{C}\left(\mathrm{NaBH}_{4}\right)$ was $56.4 \mathrm{~m}^{2} \cdot \mathrm{g}^{-1}$. The electrochemical activity of the $\mathrm{Pd} / \mathrm{C}\left(\mathrm{NaBH}_{4}\right)$ was much higher than that of $\mathrm{Pd} / \mathrm{C}\left(\mathrm{NaH}_{2} \mathrm{PO}_{2}\right)$.

\section{Introduction}

Nowadays, great attention has been paid to direct alcohol fuel cell (DAFC) as portable applications due to some superior advantages over analogous devices fed with hydrogen. Direct ethanol fuel cell (DEFC) has attracted attention, since ethanol has no toxicity comparing to methanol and can be easily produced in great quantities by the fermentation of sugarcontaining raw materials $[1,2]$. The electroactivity of anodic materials is one of the main factors influencing the practical application of DAFC. Although platinum electrodes present efficient catalytic activity for alcohol oxidation, the widely practical application of Pt electrodes as anodes in DAFC is limited by the high cost of the metal platinum. If DAFC could be operated in an alkaline instead of an acidic electrolyte, it is easy to consider that the kinetics of fuel cells will be significantly improved and Pt-free electrocatalysts can be used. It is reported that $\mathrm{Pd}$ is a good electrocatalyst for ethanol oxidation and showed higher activity than that of $\mathrm{Pt}$ in alkaline media $[3,4]$.

Recently, nanoparticle palladium has recently received much attention due to some distinguished advantages of it such as significantly large surface areas and high stability. Wen et al. [5] prepared $\mathrm{Pd} / \mathrm{SnO}_{2}$-GNS catalysts by a microwave-assisted reduction process. It was found that, compared with $\mathrm{Pd} / \mathrm{GNS}$, the $\mathrm{Pd} / \mathrm{SnO}_{2}$-GNS catalyst showed superior electrocatalytic activity for ethanol oxidation. The interest in Pd not only is for the purpose to lower the cost of catalysts but pursuits an improved catalytic activity. One method to promote the catalytic activity of $\mathrm{Pd}$ is alloying with another metal, such as Ag and Sn [6-9]. Liu et al. [10] synthesized PdNi nanoparticles by a chemical reduction process with formic acid. Zhou et al. [11] studied the electrooxidation of ethanol on a polycrystalline Pd disk electrode in alkaline media in situ Fourier transform infrared (FTIR) reflection spectroscopy. The selectivity for ethanol oxidation to $\mathrm{CO}_{2}$ (existing as $\mathrm{CO}_{3}{ }^{2-}$ in alkaline media) was determined as low as $2.5 \%$ in the potential region where Pd electrode exhibited considerable electrocatalytic activity ( -0.60 to $0.0 \mathrm{~V}$ versus SCE). Nevertheless, the ability of Pd for breaking $\mathrm{C}-\mathrm{C}$ bond in ethanol is still slightly better than that of $\mathrm{Pt}$ under the same conditions.

In the present work, we prepared two different nanoparticle $\mathrm{Pd} / \mathrm{C}$ electrocatalysts using $\mathrm{NaBH}_{4}$ and $\mathrm{NaH}_{2} \mathrm{PO}_{2}$ as reductants, respectively, to investigate the nanoparticle palladium towards ethanol oxidation reaction (EOR) in alkaline 
solution. In addition, we have also probed the electrochemical properties of the electrocatalysts to explore their potential applications in DEFC.

\section{Experimental}

2.1. Instrumentation. XRD patterns were collected using a Bruker D8-Advance Powder X-ray diffractometer $(\mathrm{Cu}$ KR radiation, wavelength $1.5418 \AA$ ). Transmission electron microscopy (TEM) images were characterized with a JEM2100F HR-TEM model using an accelerating voltage of 80 and $200 \mathrm{KV} .10 .0 \mathrm{mg}$ catalyst was dissolved in aqua regia (a strong acid mixture with $\mathrm{HCl}: \mathrm{HNO}_{3}$ volume ratio of $3: 1$ ) to form a Pd aqueous solution, and ICP-AES was performed to detect the catalyst metal loading. All electrochemical measurements were performed in a standard three-electrode cell using a $\mathrm{CHI}$ 660C Electrochemical Analyzer.

2.2. Reagents and Solutions. All reagents used were of high purity and analytical reagent grade. $\mathrm{PdCl}_{2}$ was purchased from the Shanghai Institute of Fine Chemical Materials (China); Vulcan XC-72 was supplied by Cabot Co. Ltd. (USA); Sodium borohydride $\left(96 \%, \mathrm{NaBH}_{4}\right)$, Sodium hypophosphite hydrate $\left(\mathrm{NaH}_{2} \mathrm{PO}_{2} \cdot \mathrm{H}_{2} \mathrm{O}\right)$, Trisodium citrate dehydrate $\left(\mathrm{C}_{6} \mathrm{H}_{5} \mathrm{Na}_{3} \mathrm{O}_{7} \cdot 2 \mathrm{H}_{2} \mathrm{O}\right)$ ethanol, and ethylene glycol were from Sinopharm Chemical Reagent Co. Ltd. 5\% Nafion solution was from DuPont Co. Ltd (USA); all other reagents were of analytical grade and used without further purification. The water utilized in all studies was double distilled and deionized.

2.3. Catalyst Preparation. XC-72 carbon was treated in $5 \mathrm{M}$ $\mathrm{HNO}_{3}$ solution with vigorous stirring. $40.0 \mathrm{mg}$ of the prepared carbon and $2 \mathrm{mmol} \mathrm{L}^{-1} \mathrm{PdCl}_{2}$ aqueous solution were added in a mixture of deionized water and ethylene glycol $(\mathrm{V} / \mathrm{V}, 3: 1)$. The mixture was stirred for $1 \mathrm{~h}$. After that, the appropriate amount of $\mathrm{C}_{6} \mathrm{H}_{5} \mathrm{Na}_{3} \mathrm{O}_{7} \cdot 2 \mathrm{H}_{2} \mathrm{O}$ was added into the mixture as stabilizing agent and then put into an ultrasonic bath, keeping the temperature at $50^{\circ} \mathrm{C}$ for $0.5 \mathrm{~h}$ in continuous ultrasonic concussion. Subsequently, adjust $\mathrm{pH}$ to 11 using $1 \mathrm{M} \mathrm{NaOH}$ aqueous solution; excess amounts of $0.01 \mathrm{M}$ $\mathrm{NaBH}_{4}$ (freshly prepared) were added into the mixtures dropwise. After being stirred for $6 \mathrm{~h}$ at $50^{\circ} \mathrm{C}$, the mixture was filtered and washed several times with deionized water to completely remove all excess reducing agents. The remaining solids were dried in a vacuum oven for $24 \mathrm{~h}$ at $80^{\circ} \mathrm{C}$. The final catalyst was $\mathrm{Pd} / \mathrm{C}\left(\mathrm{NaBH}_{4}\right) . \mathrm{Pd} / \mathrm{C}\left(\mathrm{NaH}_{2} \mathrm{PO}_{2}\right)$ was prepared by the similar method using Sodium hypophosphite hydrate as a reducing agent. The weight percentage of Pd was $20 \%$ in both catalysts.

2.4. Electrochemical Measurements. Cyclic voltammetry (CV) and chronoamperometry measurements were collected in $1 \mathrm{M} \mathrm{KOH}+1 \mathrm{M}$ ethanol solution at a scan rate of $50 \mathrm{mV} \cdot \mathrm{s}^{-1}$. The working electrodes were prepared by dropping $4 \mu \mathrm{L}$ of the electrocatalyst onto glassy carbon electrode (GCE, $0.07 \mathrm{~cm}^{2}$ ). The ink was prepared by ultrasonically mixing $5 \mathrm{mg}$ of electrocatalyst sample in a mixture of $1 \mathrm{~mL}$ of ethanol and $120 \mu \mathrm{L}$ of $5 \%$ Nafion solution. The counter electrode was large Pt foils, and the reference electrode was saturated calomel electrode (SCE). The CV tests were carried out in the potential range of -0.8 to $0.4 \mathrm{~V}$. Before experiments, pure nitrogen gas (99.99\%) was bubbled through the solution at the last $30 \mathrm{~min}$ to remove the dissolved oxygen in the solution. $\mathrm{CO}$ striping voltammetric measurements were performed as follows: after purging the solution with $\mathrm{N}_{2}$ for $30 \mathrm{~min}$, gaseous $\mathrm{CO}$ was bubbled for $30 \mathrm{~min}$ to form $\mathrm{CO}$ adlayer on catalysts while maintaining potential at $-0.6 \mathrm{~V}$. Excess $\mathrm{CO}$ in solution was purged with $\mathrm{N}_{2}$ for $2 \mathrm{~h}$ and $\mathrm{CO}$ stripping voltammetry was recorded in $1 \mathrm{M} \mathrm{KOH}$ at $50 \mathrm{mV} \cdot \mathrm{s}^{-1}$. All experiments were carried out at ambient temperature $\left(\sim 25^{\circ} \mathrm{C}\right)$.

\section{Results and Discussion}

3.1. TEM. Figure 1 shows typical TEM images of the $\mathrm{Pd} / \mathrm{C}$ $\left(\mathrm{NaBH}_{4}\right)$ and $\mathrm{Pd} / \mathrm{C}\left(\mathrm{NaH}_{2} \mathrm{PO}_{2}\right)$ catalysts. The catalysts prepared by the reduction method are spherical and homogeneously dispersed on Vulcan XC-72 with no remarkable observation of agglomerations. The average diameters of both catalysts are also summarized in Table 1 . They are 3.3 and $38.0 \mathrm{~nm}$ for $\mathrm{Pd} / \mathrm{C}\left(\mathrm{NaBH}_{4}\right)$ and $\mathrm{Pd} / \mathrm{C}\left(\mathrm{NaH}_{2} \mathrm{PO}_{2}\right)$. Obviously, $\mathrm{Pd} / \mathrm{C}\left(\mathrm{NaBH}_{4}\right)$ has a smaller particle size than $\mathrm{Pd} / \mathrm{C}\left(\mathrm{NaH}_{2} \mathrm{PO}_{2}\right)$.

3.2. XRD. The $\mathrm{X}$-ray diffraction (XRD) patterns of the $\mathrm{Pd} / \mathrm{C}\left(\mathrm{NaBH}_{4}\right)$ and $\mathrm{Pd} / \mathrm{C}\left(\mathrm{NaH}_{2} \mathrm{PO}_{2}\right)$ catalysts are shown in Figure 2. Sharp and well-defined peaks of $\mathrm{Pd} / \mathrm{C}\left(\mathrm{NaH}_{2} \mathrm{PO}_{2}\right)$ are observed at $2 \theta$ values of $40.14^{\circ}, 46.69^{\circ}, 68.17^{\circ}, 82.17^{\circ}$, and $86.69^{\circ}$ corresponding to planes of (1 111$)$, ( $\left.\begin{array}{lll}2 & 0 & 0\end{array}\right),\left(\begin{array}{lll}2 & 2 & 0\end{array}\right)$, (3 1 1), and (2 2 2), respectively, according to JCPDS No.656174. The strong diffraction peaks of $\mathrm{Pd} / \mathrm{C}\left(\mathrm{NaBH}_{4}\right)$ are also found in the same angles, but the plane of (2 22 2) disappears. Combined with the TEM images, it is indicated that the crystalline structure of palladium was obtained, respectively, using $\mathrm{NaBH}_{4}$ and $\mathrm{NaH}_{2} \mathrm{PO}_{2}$ as reductants.

The average particle size of the nanoparticles $(d)$ was estimated by using Scherrer equation (1) after background subtraction from (1 111$)$ peak at $2 \theta$ of $\sim 40^{\circ}$ [12]:

$$
d=\frac{k \lambda}{\beta \cos \theta},
$$

where $k$ is the coefficient, generally taken as $0.9, \lambda$ is wavelength of $\mathrm{X}$-ray radiation equal to $1.5418 \AA, \beta$ is full width at half maximum (FWHM) measured in radians, and $\theta$ is the angle measured at the position of platinum peaks. Table 1 shows the crystalline size of the electrocatalysts.

3.3. Electrochemical Measurements. Cyclic voltammetry was used to quantify the electrocatalytic activities of the $\mathrm{Pd} / \mathrm{C}$ as prepared for room temperature. Figure 3 shows the $\mathrm{CV}$ results of $\mathrm{Pd} / \mathrm{C}\left(\mathrm{NaBH}_{4}\right)$ and $\mathrm{Pd} / \mathrm{C}\left(\mathrm{NaH}_{2} \mathrm{PO}_{2}\right)$ in $1 \mathrm{~mol} \cdot \mathrm{L}^{-1}$ $\mathrm{C}_{2} \mathrm{H}_{5} \mathrm{OH}+1 \mathrm{~mol} \cdot \mathrm{L}^{-1} \mathrm{KOH}$ solution. The scan rate was selected at $50 \mathrm{mV} \cdot \mathrm{s}^{-1}$ in the potential range from -0.8 to 0.4 $\mathrm{V}$. The oxidation peak in the forward scan is corresponding to the oxidation of freshly chemisorbed species coming from ethanol adsorption. At a higher potential, the formation of 



(a)


(b)

Figure 1: TEM images and particle size distributions of $\mathrm{Pd} / \mathrm{C}\left(\mathrm{NaBH}_{4}\right)$ (a) and $\mathrm{Pd} / \mathrm{C}\left(\mathrm{NaH}_{2} \mathrm{PO}_{2}\right)$ (b).

TABLE 1: Summary of physical properties of $\mathrm{Pd} / \mathrm{C}\left(\mathrm{NaBH}_{4}\right)$ and $\mathrm{Pd} / \mathrm{C}$ $\left(\mathrm{NaH}_{2} \mathrm{PO}_{2}\right)$ catalysts.

\begin{tabular}{lccc}
\hline Catalyst & $\begin{array}{c}\text { Pd metal } \\
\text { loading } \\
\text { detected by } \\
\text { ICP-AES }\end{array}$ & $\begin{array}{c}\text { Diameter } \\
\text { calculated } \\
\text { form XRD/nm }\end{array}$ & $\begin{array}{c}\text { Diameter } \\
\text { measured by } \\
\text { TEM/nm }\end{array}$ \\
\hline $\mathrm{Pd} / \mathrm{C}\left(\mathrm{NaBH}_{4}\right)$ & $21.6 \%$ & 2.8 & 3.3 \\
$\mathrm{Pd} / \mathrm{C}$ & $23.8 \%$ & 3.4 & 38.0 \\
$\left(\mathrm{NaH}_{2} \mathrm{PO}_{2}\right)$ & & & \\
\hline
\end{tabular}

PdO will block further adsorption of reactive species and lead to a remarkable decrease in current. During the negativegoing sweep, the previously formed $\mathrm{PdO}$ will be reduced to catalytic active $\mathrm{Pd}$, thus, leading to the recovery of EOR current. Corresponding reactions are shown in (2) and (3) [13]:

$$
\begin{gathered}
\mathrm{Pd}+\mathrm{C}_{2} \mathrm{H}_{5} \mathrm{OH}+3 \mathrm{OH}^{-} \longleftrightarrow \mathrm{Pd}_{-} \mathrm{CH}_{3} \mathrm{CO}_{\mathrm{ads}}+3 \mathrm{H}_{2} \mathrm{O}+3 \mathrm{e} \\
\mathrm{Pd}-\mathrm{CH}_{3} \mathrm{CO}_{\mathrm{ads}}+\mathrm{Pd}-\mathrm{OH}_{\mathrm{ads}}+\mathrm{OH}^{-} \\
\longrightarrow 2 \mathrm{Pd}+\mathrm{CH}_{3} \mathrm{COO}^{-}+\mathrm{H}_{2} \mathrm{O}
\end{gathered}
$$

It is observed from Figure 3 that the current density on $\mathrm{Pd} / \mathrm{C}\left(\mathrm{NaBH}_{4}\right)$ is obviously higher, compared with that on $\mathrm{Pd} / \mathrm{C}\left(\mathrm{NaH}_{2} \mathrm{PO}_{2}\right)$. It shows that the $\mathrm{Pd} / \mathrm{C}\left(\mathrm{NaBH}_{4}\right)$ catalyst has a better catalytic activity. In the forward scan, the onset potential $\left(E_{\text {onset }}\right)$ of $\mathrm{Pd} / \mathrm{C}\left(\mathrm{NaBH}_{4}\right)$ is $-0.544 \mathrm{~V}$, which have negatively shifts by $\sim 30 \mathrm{mV}$ as compared to that of $\mathrm{Pd} / \mathrm{C}$ $\left(\mathrm{NaH}_{2} \mathrm{PO}_{2}\right)(-0.516 \mathrm{~V})$. The peak current densities are 28.8 and $17.4 \mathrm{~mA} \cdot \mathrm{cm}^{-2}$ (the area is the surface area of the electrode) for $\mathrm{Pd} / \mathrm{C}\left(\mathrm{NaBH}_{4}\right)$ and $\mathrm{Pd} / \mathrm{C}\left(\mathrm{NaH}_{2} \mathrm{PO}_{2}\right)$, respectively, while their peak potentials are -0.258 and $-0.232 \mathrm{~V}$. The following parameters, including the $E_{\text {onset }}$, the forward peak potential $\left(E_{p}\right)$, and the forward peak current intensity $\left(j_{p}\right)$ expressed in $\mathrm{mA} \cdot \mathrm{cm}^{-2}$, are shown in Table 2. At the same time, the peak current density of $\mathrm{Pd} / \mathrm{C}\left(\mathrm{NaBH}_{4}\right)$ is higher than that of $\mathrm{Pd} / \mathrm{C}$ in $[7,14]$.

When compared to $\mathrm{NaH}_{2} \mathrm{PO}_{2}$ reduction method, the $\mathrm{NaBH}_{4}$ reduction method shows a great advantage in improving the EOR activity. The main reason is that $\mathrm{NaBH}_{4}$ exhibits a higher reduction rate; it is beneficial to maintain high saturation degree during the nucleation stage at the beginning of reaction. On the other hand, the concentrations of $\mathrm{BH}_{4}{ }^{-}$ and $\mathrm{H}_{2} \mathrm{PO}_{2}{ }^{-}$decide the reduction ability of $\mathrm{NaBH}_{4}$ and 




口 Pd

Figure 2: XRD patterns of Pd/C $\left(\mathrm{NaBH}_{4}\right)$ and $\mathrm{Pd} / \mathrm{C}\left(\mathrm{NaH}_{2} \mathrm{PO}_{2}\right)$.

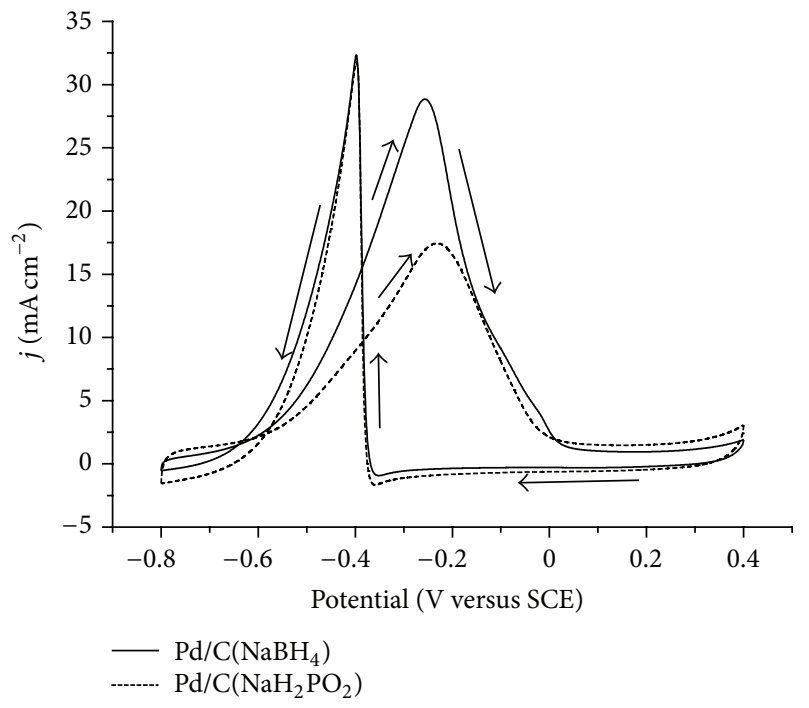

Figure 3: Voltammetric curves of $\mathrm{Pd} / \mathrm{C}\left(\mathrm{NaBH}_{4}\right)$ and $\mathrm{Pd} / \mathrm{C}$ $\left(\mathrm{NaH}_{2} \mathrm{PO}_{2}\right)$ in $1 \mathrm{~mol} \cdot \mathrm{L}^{-1} \mathrm{C}_{2} \mathrm{H}_{5} \mathrm{OH}+1 \mathrm{~mol} \cdot \mathrm{L}^{-1} \mathrm{KOH}$ solution.

TABLE 2: Comparison of activity of ethanol oxidation between $\mathrm{Pd} / \mathrm{C}$ $\left(\mathrm{NaBH}_{4}\right)$ and $\mathrm{Pd} / \mathrm{C}\left(\mathrm{NaH}_{2} \mathrm{PO}_{2}\right)$ catalysts.

\begin{tabular}{lcccc}
\hline Catalyst & $E_{\text {onset }} / \mathrm{V}$ & $E_{p} / \mathrm{V}$ & $j_{p} / \mathrm{mA} \cdot \mathrm{cm}^{-2}$ & $\mathrm{EASA} / \mathrm{m}^{2} \cdot \mathrm{g}^{-1}$ \\
\hline $\mathrm{Pd} / \mathrm{C}\left(\mathrm{NaBH}_{4}\right)$ & -0.544 & -0.258 & 28.8 & 56.4 \\
$\mathrm{Pd} / \mathrm{C}\left(\mathrm{NaH}_{2} \mathrm{PO}_{2}\right)$ & -0.516 & -0.232 & 17.4 & 51.2 \\
\hline
\end{tabular}

$\mathrm{NaH}_{2} \mathrm{PO}_{2}$, respectively. In alkaline condition, the hydrolysis of $\mathrm{BH}_{4}{ }^{-}$is inhibited, (4), but the hydrolysis of $\mathrm{H}_{2} \mathrm{PO}_{2}{ }^{-}$is promoted, (5):

$$
\begin{gathered}
\mathrm{BH}_{4}{ }^{-}+2 \mathrm{H}_{2} \mathrm{O}=\mathrm{BO}_{2}{ }^{-}+4 \mathrm{H}_{2} \uparrow \\
\mathrm{H}_{2} \mathrm{PO}_{2}{ }^{-}+\mathrm{OH}^{-}=\mathrm{HBO}_{2}{ }^{2-}+\mathrm{H}_{2} \uparrow
\end{gathered}
$$



FIgUre 4: Voltammetric curves of $\mathrm{Pd} / \mathrm{C}\left(\mathrm{NaBH}_{4}\right)$ and $\mathrm{Pd} / \mathrm{C}$ $\left(\mathrm{NaH}_{2} \mathrm{PO}_{2}\right)$ in $1 \mathrm{~mol} \cdot \mathrm{L}^{-1} \mathrm{KOH}$ solution.

The cyclic voltammetry of $\mathrm{Pd} / \mathrm{C}\left(\mathrm{NaBH}_{4}\right)$ and $\mathrm{Pd} / \mathrm{C}$ $\left(\mathrm{NaH}_{2} \mathrm{PO}_{2}\right)$ in the absence of ethanol is shown in Figure 4. It is observed from Figure 4 that they exhibit significantly high anodic and cathodic current densities. The oxidation peak at lower anodic potential during the forward scan is ascribed to the formation of the adsorbed hydroxyl $\mathrm{OH}_{\text {ads }}$ while this at high positive potential is related to the formation of Pd oxides $[15,16]$. On the cathodic scan, the palladium oxide layers are reduced, with reduction peaks at -0.512 and -0.431 , respectively. The potential region from -1.1 to $-0.7 \mathrm{~V}$ versus SCE on the CV curve of the catalyst is associated with the hydrogen adsorption/desorption. The electrochemical active surface areas (EASA) of catalysts were measured by integrating the charge on hydrogen adsorption-desorption regions by cyclic voltammetry. These values given in Table 1 can be calculated after the deduction of the double layer region on the $\mathrm{CV}$ curves represents the charge passed for the hydrogen desorption. The electrochemical active surface areas (EASA) for $\mathrm{Pd} / \mathrm{C}\left(\mathrm{NaBH}_{4}\right)$ and $\mathrm{Pd} / \mathrm{C}\left(\mathrm{NaH}_{2} \mathrm{PO}_{2}\right)$ were calculated to be 56.4 and $51.2 \mathrm{~m}^{2} \cdot \mathrm{g}^{-1}$, respectively (Table 2). Obviously, $\mathrm{Pd} / \mathrm{C}\left(\mathrm{NaBH}_{4}\right)$ shows a better electrochemical activity because of higher EASA.

In order to evaluate the stability of the catalysts, chronoamperometry was employed and results are shown in Figure 5. The present results show that the current densities represent less decay at the applied constant potentials for a long duration $(3600 \mathrm{~s})$. It can be observed that the current densities on the $\mathrm{Pd} / \mathrm{C}\left(\mathrm{NaBH}_{4}\right)$ and $\mathrm{Pd} / \mathrm{C}\left(\mathrm{NaH}_{2} \mathrm{PO}_{2}\right)$ after $3600 \mathrm{~s}$ are 0.6 and $0.1 \mathrm{~mA} \cdot \mathrm{cm}^{-2}$, indicating that the $\mathrm{Pd} / \mathrm{C}$ $\left(\mathrm{NaBH}_{4}\right)$ exhibits a better stable electrocatalytic activity towards ethanol oxidation in the alkaline media than $\mathrm{Pd} / \mathrm{C}$ $\left(\mathrm{NaH}_{2} \mathrm{PO}_{2}\right)$. The results are in accordance with the $\mathrm{CV}$ results.

CO striping voltammetric curves are shown in Figure 6. The CO striping measurements are conducted in $1 \mathrm{M} \mathrm{KOH}$. 




Figure 5: Chronoamperometry curves of $\mathrm{Pd} / \mathrm{C}\left(\mathrm{NaBH}_{4}\right)$ and $\mathrm{Pd} / \mathrm{C}$ $\left(\mathrm{NaH}_{2} \mathrm{PO}_{2}\right)$ in $1 \mathrm{~mol} \cdot \mathrm{L}^{-1} \mathrm{C}_{2} \mathrm{H}_{5} \mathrm{OH}+1 \mathrm{~mol} \cdot \mathrm{L}^{-1} \mathrm{KOH}$ solution at a fixed potential of $-300 \mathrm{mV}$ for $3600 \mathrm{~s}$.



FIGURE 6: $\mathrm{CO}$ striping voltammetric curves of $\mathrm{Pd} / \mathrm{C}\left(\mathrm{NaBH}_{4}\right)$ and $\mathrm{Pd} / \mathrm{C}\left(\mathrm{NaH}_{2} \mathrm{PO}_{2}\right)$ in $1 \mathrm{~mol} \cdot \mathrm{L}^{-1} \mathrm{KOH}$ solution.

It is observed from $\mathrm{Pd} / \mathrm{C}\left(\mathrm{NaBH}_{4}\right)$ (solid line) that an anodic peak with a shoulder an the high potential side appears in the potential from -0.3 to $-0.1 \mathrm{~V}$. In contrast to $\mathrm{Pd} / \mathrm{C}\left(\mathrm{NaBH}_{4}\right)$, the $\mathrm{Pd} / \mathrm{C}\left(\mathrm{NaH}_{2} \mathrm{PO}_{2}\right)$ (dash line) possesses a smaller $\mathrm{CO}$ stripping peak, indicating that a less amount of $\mathrm{CO}$ molecules adsorb on the active surface of $\mathrm{Pd} / \mathrm{C}\left(\mathrm{NaH}_{2} \mathrm{PO}_{2}\right)$. Moreover, the simple and sharp line profile of the stripping peak observed for the $\mathrm{Pd} / \mathrm{C}\left(\mathrm{NaBH}_{4}\right)$ demonstrates that the structure of the sample is relatively homogeneous [17]. After stripping, sharp peaks of two CV curves are disappeared in the 2 nd cycle. It indicates that the CO preadsorbed on the surface of electrocatalysts is thoroughly oxidized in the first potential scan and the active sites on the Pd surface recover again.

CO has been commonly identified as an intermediate, and the major poisonous species in the alcohol oxidation process, that is prone to adsorb on the surface active sites of electrocatalysts, has been widely used as an effective method to evaluate the active surface area of electrocatalysts [18].

\section{Conclusions}

In summary, two different $20 \mathrm{wt} \%$ nanoparticle $\mathrm{Pd} / \mathrm{C}$ electrocatalysts were prepared with $\mathrm{NaBH}_{4}$ and $\mathrm{NaH}_{2} \mathrm{PO}_{2}$ as reductants, respectively. $\mathrm{Pd} / \mathrm{C}\left(\mathrm{NaBH}_{4}\right)$ catalysts have small average diameter $(3.3 \mathrm{~nm})$ and large electrochemical surface areas $\left(56.4 \mathrm{~m}^{2} \cdot \mathrm{g}^{-1}\right)$. Therefore, $\mathrm{Pd} / \mathrm{C}\left(\mathrm{NaBH}_{4}\right)$ exhibits higher reactivity toward $\mathrm{EOR}$ in alkaline electrolyte, compared to $\mathrm{Pd} / \mathrm{C}\left(\mathrm{NaH}_{2} \mathrm{PO}_{2}\right)$. The $\mathrm{CV}$ tests show that the $E_{\text {onset }}$ on $\mathrm{Pd} / \mathrm{C}$ $\left(\mathrm{NaBH}_{4}\right)$ is more negative than that of $\mathrm{Pd} / \mathrm{C}\left(\mathrm{NaH}_{2} \mathrm{PO}_{2}\right)$; the peak current densities of $\mathrm{Pd} / \mathrm{C}\left(\mathrm{NaBH}_{4}\right)\left(28.8 \mathrm{~mA} \cdot \mathrm{cm}^{-2}\right)$ are higher than those of $\mathrm{Pd} / \mathrm{C}\left(\mathrm{NaH}_{2} \mathrm{PO}_{2}\right)\left(17.4 \mathrm{~mA} \cdot \mathrm{cm}^{-2}\right)$. After a $3600 \mathrm{~s}$ chronoamperometry test at $-0.3 \mathrm{~V}, \mathrm{Pd} / \mathrm{C}$ $\left(\mathrm{NaBH}_{4}\right)$ exhibits a better stable electrocatalytic activity towards ethanol oxidation in the alkaline media than $\mathrm{Pd} / \mathrm{C}$ $\left(\mathrm{NaH}_{2} \mathrm{PO}_{2}\right)$.

\section{Acknowledgments}

This project was supported by the National Science Foundation of China (21103107), Innovation Program of Shanghai Municipal Education Commission, China (09YZ339, 10ZZ116), Key Project of Shanghai Committee of Science and technology, China (09230501400, 10160502300), and Talent Development Fund of Shanghai, China.

\section{References}

[1] E. M. Cunha, J. Riberto, K. B. Kokoh, and A. R. de Anerade, "Preparation, characterization and application of Pt-Ru-Sn/C trimetallic electro-catalysts for ethanol oxidation in direct fuel cell," International Journal of Hydrogen Energy, vol. 36, no. 17, pp. 11034-11042, 2011.

[2] B. R. Tao, J. Zhang, S. C. Hui, X. J. Chen, and L. J. Wan, "An electrochemical methanol sensor based on a $\mathrm{Pd}-\mathrm{Ni} / \mathrm{SiNWs}$ catalytic electrode," Electrochimica Acta, vol. 55, no. 17, pp. 50195023, 2010.

[3] T. Ogi, R. Honda, K. Tamaoki, N. Saitoh, and Y. Konishi, "Direct room-temperature synthesis of a highly dispersed Pd nanoparticle catalyst and its electrical properties in a fuel cell," Powder Technology, vol. 205, no. 1-3, pp. 143-148, 2011.

[4] C. Mahendiran, T. Maiyalagan, K. Scott, and A. Gedanken, "Synthesis of a carbon-coated $\mathrm{NiO} / \mathrm{MgO}$ core/shell nanocomposite as a Pd electro-catalyst support for ethanol oxidation," Materials Chemistry and Physics, vol. 128, no. 3, pp. 341-347, 2011.

[5] Z. L. Wen, S. D. Yang, Y. Y. Liang et al., "The improved electrocatalytic activity of palladium/graphene nanosheets towards ethanol oxidation by tin oxide," Electrochimica Acta, vol. 56, no. 1, pp. 139-144, 2010.

[6] J. Kim, T. Momma, and T. Osaka, "Cell performance of Pd-Sn catalyst in passive direct methanol alkaline fuel cell using anion 
exchange membrane," Journal of Power Sources, vol. 189, no. 2, pp. 999-1002, 2009.

[7] M. C. Oliveira, R. Rego, L. S. Fernandes, and P. B. Tavares, "Evaluation of the catalytic activity of Pd-Ag alloys on ethanol oxidation and oxygen reduction reactions in alkaline medium," Journal of Power Sources, vol. 196, no. 15, pp. 6092-6098, 2011.

[8] Y. Wang, Z. M. Sheng, H. Yang, S. P. Jiang, and C. M. $\mathrm{Li}$, "Electrocatalysis of carbon black- or activated carbon nanotubes-supported $\mathrm{Pd}-\mathrm{Ag}$ towards methanol oxidation in alkaline media," International Journal of Hydrogen Energy, vol. 35, no. 19, pp. 10087-10093, 2010.

[9] Y. W. Tang, S. Cao, Y. Chen et al., "Effect of Fe state on electrocatalytic activity of $\mathrm{Pd}-\mathrm{Fe} / \mathrm{C}$ catalyst for oxygen reduction," Applied Surface Science, vol. 256, no. 13, pp. 4196-4200, 2010.

[10] Z. L. Liu, X. H. Zhang, and L. Hong, "Physical and electrochemical characterizations of nanostructured $\mathrm{Pd} / \mathrm{C}$ and $\mathrm{PdNi} / \mathrm{C}$ catalysts for methanol oxidation," Electrochemistry Communications, vol. 11, no. 4, pp. 925-928, 2009.

[11] Z. Y. Zhou, Q. Wang, J. L. Lin, N. Tian, and S. G. Sun, "In situ FTIR spectroscopic studies of electrooxidation of ethanol on Pd electrode in alkaline media," Electrochimica Acta, vol. 55, no. 27, pp. 7995-7999, 2010.

[12] V. Radmilovic, H. A. Gasteiger, and P. N. Ross, "Structure and chemical composition of a supported Pt-Ru electrocatalyst for methanol oxidation," Journal of Catalysis, vol. 154, no. 1, pp. 98106, 1995.

[13] Q. F. Yi, F. J. Niu, and L. Z. Sun, "Fabrication of novel porous Pd particles and their electroactivity towards ethanol oxidation in alkaline media," Fuel, vol. 90, no. 8, pp. 2617-2623, 2011.

[14] Y. Wang, T. S. Nguyen, X. W. Liu, and X. Wang, "Novel palladium-lead ( $\mathrm{Pd}-\mathrm{Pb} / \mathrm{C})$ bimetallic catalysts for electrooxidation of ethanol in alkaline media," Journal of Power Sources, vol. 195, no. 9, pp. 2619-2622, 2010.

[15] Z. Y. Zhang, L. Xin, K. Sun, and W. Z. Li, "Pd-Ni electrocatalysts for efficient ethanol oxidation reaction in alkaline electrolyte," International Journal of Hydrogen Energy, vol. 36, no. 20, pp. 12686-12697, 2011.

[16] A. Maghsodi, M. R. M. Hoseini, M. D. Mobarakeh et al., "Exploration of bimetallic Pt-Pd/C nanoparticles as an electrocatalyst for oxygen reduction reaction," Applied Surface Science, vol. 257, no. 15, pp. 6353-6357, 2011.

[17] M. Hara, U. Linke, and T. Wandlowski, "Preparation and electrochemical characterization of palladium single crystal electrodes in $0.1 \mathrm{M} \mathrm{H}_{2} \mathrm{SO}_{4}$ and $\mathrm{HClO}_{4}$-part I: low-index phases," Electrochimica Acta, vol. 52, no. 18, pp. 5733-5748, 2007.

[18] Y. J. Huang, X. C. Zhou, J. H. Liao, C. P. Liu, T. H. Lu, and W. Xing, "Preparation of $\mathrm{Pd} / \mathrm{C}$ catalyst for formic acid oxidation using a novel colloid method," Electrochemistry Communications, vol. 10, no. 4, pp. 621-624, 2008. 



\section{Carbohydrate} Chemistry



The Scientific World Journal



Submit your manuscripts at

http://www.hindawi.com



Analytical Methods

in Chemistry



Journal of

Applied Chemistry



Inorganic Chemistry
